DOI: $10.25140 / 2411-5215-2020-3(23)-158-165$

Андрій Роговий, Максим Дубина, Тетяна Забаштанська

\title{
СТРАТЕГІЧНІ ПРІОРИТЕТИ РОЗВИТКУ СФЕРИ ОХОРОНИ ЗДОРОВ'Я В УКРАЇНІ: ФІНАНСОВІ АСПЕКТИ
}

\author{
Андрей Роговой, Максим Дубина, Татьяна Забаштанская \\ СТРАТЕГИЧЕСКИЕ ПРИОРИТЕТЫ РАЗВИТИЯ СФЕРЫ \\ ЗДРАВООХРАНЕНИЯ В УКРАИНЕ: ФИНАНСОВЫЕ АСПЕКТЫ
}

\author{
Andrii Rogovyi, Maksym Dubyna, Zabashtanska Tatiana \\ STRATEGIC PRIORITIES OF HEALTHCARE DEVELOPMENT \\ IN UKRAINE: FINANCIAL ASPECTS
}

У статті проаналізовано сучасний стан та перспективи розвитку сфери охорони здоров'я в Украӥні. Визначено роль фінансового забезпечення у забезпеченні можливості ефективного функиіонування сфери охорони здоров'я, наданні якісних медичних послуг населенню. Проведено порівняльний аналіз державного фінансування сфери охорони здоров'я, згруповано фактори стимулюючого та обмежуючого впливу на його обсяг. Визначено, що серед ключових стратегічних пріоритетів розвитку сфери охорони здоров'я є забезпечення якості медичних послуг з одночасним гарантуванням їх доступності всім верствам населення. Обгрунтовано, щзо забезпечення високої якості та доступності медичних послуг перебуває у площині належного фінансового забезпечення галузі, що дозволить забезпечити збереження персоналу та підвищення його кваліфікаиії, впровадження відповідних передових інноваційних технологій, спрямованих на збільшенням середньої тривалості життя населення, зменшення кількості та тривалості перебігу захворювань, а також підвищення продуктивності праці працівників. Доведено, що обмеженість фінансових можливостей держави в сучасних умовах актуалізує необхідність пошуку нових фінансових інструментів розвитку фінансового забезпечення сфери охорони здоров'я, поглибленого дослідження питання щэодо можливостей впровадження обов'язкового медичного страхування.

Ключові слова: сфера охорони здоров'я; стратегічні пріоритети; фінанси; фінансові ресурси; фінансове забезпечення; фінансові важелі; ичиррова економіка.

Табл.: 1. Рис.: 1. Бібл.: 11.

В статье проанализировано современное состояние и перспективы развития сферы здравоохранения в Украине. Определена роль финансового обеспечения в формировании возможности эффективного функиионирования сферы здравоохранения, предоставлении качественных медицинских услуг населению. Проведено сравнительный анализ государственного финансирования сферы здравоохранения, сгруппированы факторы стимулирующего и ограничивающего влияния на его объем. Определено, что среди ключевых стратегических приоритетов развития сферы здравоохранения находится качество медииинских услуг с одновременным обеспечением их доступности всем слоям населения. Обосновано, что обеспечение высокого качества и доступности медицинских услуг находится в плоскости надлежащего финансового обеспечения отрасли, что позволит гарантировать сохранение персонала и повышение его квалификации, внедрения соответствующих передовых инновационных технологий, направленных на возрастание средней продолжстельности жизни населения, уменьшение количества и продолюительности заболеваний, а также повышение производительности труда работников. Доказано, что ограниченность финансовых возможностей государства в современных условиях актуализирует необходимость поиска новых финансовых инструментов развития финансового обеспечения здравоохранения, углубленного исследования вопроса о возможностях внедрения обязательного медицинского страхования.

Ключевые слова: сфера здравоохранения; стратегические приоритеты; финансы; финансовые ресурсы; финансовое обеспечение; финансовые рычаги; ичифровая экономика.

Табл.: 1. Рис.: 1. Библ.: 11.

The article analyzes the current state and prospects of health care development in Ukraine. The role of financial support in ensuring the possibility of effective functioning of the health care sector, providing quality medical services to the population has been determined. The comparative analysis of the state financing of the sphere of health care is carried out, the factors of stimulating and limiting influence on its volume are grouped. It is determined that among the key strategic priorities for the development of health care is ensuring the quality of medical services while ensuring their accessibility to all segments of the population. It is substantiated that ensuring high quality and accessibility of medical services is in the plane of adequate financial support of the industry, which will ensure the retention of staff and their skills, the introduction of appropriate innovative technologies aimed at increasing life expectancy, reducing the number and duration of diseases, and increasing employee productivity. It is proved that the limited financial capacity of the state in modern conditions highlights the need to find new financial instruments for the development of financial support for health care, in-depth study of the possibility of introducing compulsory health insurance.

Key words: health care; strategic priorities; finances; financial resources; financial support; financial leverage; digital economy.

Table: 1. Fig.: 1. References: 11.

JEL Classification: G17; G18; I15; I18

(C) Роговий А. В., Дубина М. В., Забаштанська Т. В., 2020 
ФІНАНСОВІ РЕСУРСИ: ПРОБЛЕМИ ФОРМУВАННЯ ТА ВИКОРИСТАННЯ

Постановка проблеми. Сучасний етап становлення економіки та суспільства країни можна вважати основоположним, оскільки саме нині відбувається формування фундаменту можливостей її подальшого розвитку. Поглиблення глобалізаційних процесів протягом багатьох останніх років спричинило наявність істотних взаємозалежностей у процесі організації економічних і фінансових відносин багатьох країн світу, окремими секторами національних економік, що в умовах військових дій на території нашої країни, а також світової пандемії COVID-19 виступило своєрідним каталізатором виникнення та поглиблення економічних криз. Загострення кризових явищ в економіці посилило соціальні дисбаланси в суспільстві, загострило соціальні суперечності, частина яких згодом трансформувалась у соціальні конфлікти та протистояння.

Саме на такому етапі сучасного розвитку суспільства загострюється необхідність переосмислення концептуальних та методологічних засад стратегічного розвитку національної економіки, визначення ролі й місця країни в міжнародній спільноті, формування дієвих механізмів забезпечення належних соціальних стандартів життєзабезпечення суспільства [10]. Відповідно до «Стратегії реформування управління державними фінансами на 2017-2020 роки» зазначено, що відсутність цілісної системи стратегічного планування не дає змоги забезпечити бюджетне планування на належному рівні та унеможливлює ефективну реалізацію пріоритетів розвитку держави [9]. Безумовно, вирішення окреслених завдань нерозривно пов'язано з розвитком сфери охорони здоров'я, збільшенням середньої тривалості життя населення, зменшенням кількості та тривалості перебігу захворювань, а також підвищенням продуктивності праці працівників.

Однак, попри провідну роль сфери охорони здоров'я у збереженні та розбудові суспільства, наявного системоутворюючого впливу на динаміку розвитку національної економіки, у нашій країні ця сфера залишається без належної уваги та підтримки з боку держави, що спричинило недоступність якісного медичного обслуговування переважної частини населення країни.

Аналіз останніх досліджень та публікацій. Питання стратегічного розвитку сфери охорони здоров'я розглядали у своїх працях такі відомі науковці, як В. Борщ, Т. Васильєва, О. Гальцова, О. Гонта, В. Горин, М. Забаштанський, В. Ільчук, О. Кириленко, І. Кичко, А. Кузнецов, Л. Кривенко, 3. Лободіна, В. Лехан, В. Маргасова, А. Мокрицька, Г. Мамонова, С. Онишко, Д. Румянцева, Ю. Сафонов, Н. Ткаченко, О. Тулай та інші.

Виділення недосліджених частин загальної проблеми. Незважаючи на значну кількість фундаментальних досліджень, проведених із цієї теми, існує необхідність подальшого вивчення та деталізації стратегічних пріоритетів розвитку сфери охорони здоров'я, що значною мірою зумовлено необхідністю швидкої адаптації галузі до умов побудови економічних та фінансових відносин у площині функціонування цифрової економіки як одного з ключових факторів забезпечення ефективного іiї функціонування, спрямованого на збереження здоров'я суспільства та розвиток національної економіки.

Таким чином, метою цього дослідження $\epsilon$ узагальнення можливих пріоритетів стратегічного розвитку сфери охорони здоров'я як системоутворюючої сфери національної економіки та збереження здоров'я нації.

Виклад основного матеріалу. Питання системного розвитку сфери охорони здоров'я в України не $\epsilon$ новим, над ним багато років працюють як учені, так і практики різної кваліфікації та спрямування. Однак попри значні прагнення сформувати високоякісну медичну систему в нашій країні, її стан, на жаль, залишається досить відмінним від аналогічних галузей провідних країн світу. Безумовно, це впливає на якість та доступність медичного обслуговування, що насамперед підтверджується показниками тривалості життя та смертності населення, за якими наша країна посідає досить низькі позиції в загальносвітовому рейтингу $[7 ; 8 ; 11]$. 
Попри тривіальність думки, ми вважаємо, що однією з ключових проблем, які стримують розвиток сфери охорони здоров'я в Україні, залишається питання належного фінансування, достатнього не лише для інноваційної модернізації основних засобів, але також і підготовку необхідного персоналу, забезпечення їхньої належної кваліфікації, гарантування гідної оплати праці.

Першочерговим стратегічним пріоритетом розвитку сфери охорони здоров'я на сьогодні, на нашу думку, є збереження персоналу та підвищення його кваліфікації, що зумовлено багатьма причинами. Так, низький рівень оплати праці лікарів і медичного персоналу поряд із відсутністю належних умов, формує передумови для пошуку ними можливостей працевлаштування за кордоном, перекваліфікації в інші спеціальності. За офіційними даними Державної служби статистики України, кількість штатних посад за 2014-2019 роки у закладах охорони здоров'я скоротилась майже на 35 тис. Зокрема, якщо у 2014 році їх обсяг становив 519 897, то у 2019 році - 484932 . Водночас треба зауважити, що брак лікарів та медичного персоналу сфера охорони здоров'я відчуває вже сьогодні, оскільки з наявних у 2019 році штатних посад майже 37 тис. залишаються вакантними, що становить 7,5 \% від загального обсягу. Кількість вакантних посад лікарів у 2019 становить - 10 706, середнього медичного персоналу - 12 687, посад молодшого та іншого персоналу - 12 787. Безперечно, певною мірою загальне скорочення чисельності лікарів і медичного персоналу можна пояснити наявними негативними демографічними тенденціями в країні, проте навіть з їх урахуванням, потреба у персоналі сфери охорони здоров'я $є$ очевидною. Крім того, якщо проблему покриття потреби в середньому та молодшому медичному персоналі, за умови належного рівня оплати праці, можна вирішити у порівняно короткостроковій перспективі, то підготовка висококваліфікованих лікарів перебуває в достатньо довготривалій перспективі.

Залучення професійних лікарів і медичного персоналу з інших країн також вважається малоймовірним, оскільки ми будемо не в змозі сформувати для них істотні переваги в умовах та розмірі оплати праці. Сукупність вищезазначених факторів виводить менеджмент персоналу у вітчизняній сфері охорони здоров'я на ключове місце серед стратегічних пріоритетів іiі розвитку.

Звичайно, якість функціонування сфери охорони здоров'я забезпечується синергетичним ефектом можливості використання висококваліфікованим персоналом сучасного медичного обладнання. Саме таке поєднання дозволяє отримувати максимальні результати спрямовані на вчасне діагностування, попередження, а також призначення ефективного лікування можливих хвороб. Це дозволяє значно скорочувати тривалість амбулаторного лікування, дає можливість здійснювати профілактичне лікування в домашніх умовах, що має безпосередній вплив на продуктивність праці населення, а отже, і результативність функціонування відповідних суб'єктів господарювання, економіки країни загалом. Водночас профілактика можливих захворювань не потребує значних обсягів фінансових ресурсів, на відміну від лікування хронічних випадків. Саме тому забезпечення інноваційного оновлення медичного обладнання є стратегічним пріоритетом іiі розвитку, що особливо актуалізується в умовах цифровізації світової та національної економіки.

Вирішення кожного з вищезгаданих пріоритетів стратегічного розвитку сфери охорони здоров'я, прямо чи опосередковано перебуває в площині достатності фінансового забезпечення, ефективності його використання.

Нині у світовій практиці більшості країн світу серед основних джерел фінансування сфери охорони здоров'я виокремлюють такі, як бюджетне фінансування, добровільні внески фізичних та юридичних осіб, оплата послуг приватних медичних установ, фінансові ресурси фондів добровільного медичного страхування. Проте у вітчизняних умовах розраховувати на зростання обсягів фінансового забезпечення сфери охорони здоров'я без реального зростання темпів розвитку національної економіки вважається малоймовірним. Крім того, порівняно низька результативність функціонування реаль- 
ФІНАНСОВІ РЕСУРСИ: ПРОБЛЕМИ ФОРМУВАННЯ ТА ВИКОРИСТАННЯ

ного сектору, а також значний обсяг тіньового сектору економіки унеможливлює належне формування доходної частини бюджетів відповідних рівні. За офіційними даними Кабінету Міністрів України станом на 2019 рік від 4 до 8 млн наших громадян перебувають у трудовій міграції за кордоном.

Загалом поділяючи усталену думку суспільства про позитивний вплив фінансових ресурсів, які перераховують трудові мігранти, отримані як оплату власної праці, до нашої країни на стан валютних запасів та національну економіку, не слід забувати про те, що ця категорія громадян переважно намагається уникати оподаткування власних доходів, а отже, бюджети відповідних рівнів недоотримають відповідний обсяг доходів. Водночас ці громадяни по мірі можливості та необхідності користуються певними соціальними та іншими послугами, виконання яких є обов'язком органів державної влади та місцевого самоврядування. Саме тому держава передусім зобов'язана формувати умови для працевлаштування власних громадян, забезпечувати їм гідний рівень оплати праці, що дозволить їм залишатись у країні, створювати додаткову вартість на вітчизняних підприємствах, установах, організаціях та забезпечувати формування податкових надходжень до бюджетів відповідних рівнів. За таких умов держава буде в змозі сформувати належний обсяг фінансування всіх без винятку галузей та сфер національної економіки, у тому числі і сфери охорони здоров'я.

Проведений аналіз динаміки видатків зведеного бюджету України на сферу охорони здоров’я України за 2015-2019 роки засвідчив поступове зростання їх обсягу (таблиця). Так, протягом зазначеного періоду загальний обсяг видатків збільшився на 180,8 \%, або на 57 383,4 млн грн. У структурі видатків сфери охорони здоров'я найбільшу питому вагу протягом усього періоду дослідження займають видатки на лікарні та санаторнокурортні заклади, питома вага яких у 2019 році становила 56,3 \%. Питома вага видатків на поліклініки, амбулаторії, швидку та невідкладну допомогу у 2019 році становила 12,38 \%. Однак, незважаючи на поступове абсолютне зростання обсягу видатків, які держава спрямовує на фінансування сфери охорони здоров'я, їхня питома вага у валовому внутрішньому продукті залишається порівняно низькою, а також зазнає скорочення. Так, якщо у 2015 році держава витрачала на сферу охорону здоров'я 4,96 \% ВВП, то у 2019 році цей обсяг скоротився до 3,49\%. За даними Organization for Economic Cooperation and Development у 2018 році найбільшу питому вагу витрат на охорону здоров'я у ВВП мали США - 16,9 \%, найменший обсяг мала Індія - 3,6 \%. Середній обсяг витрат на охорону здоров'я як частки ВВП коливається в межах 8-10\%, рис. 1 [5].

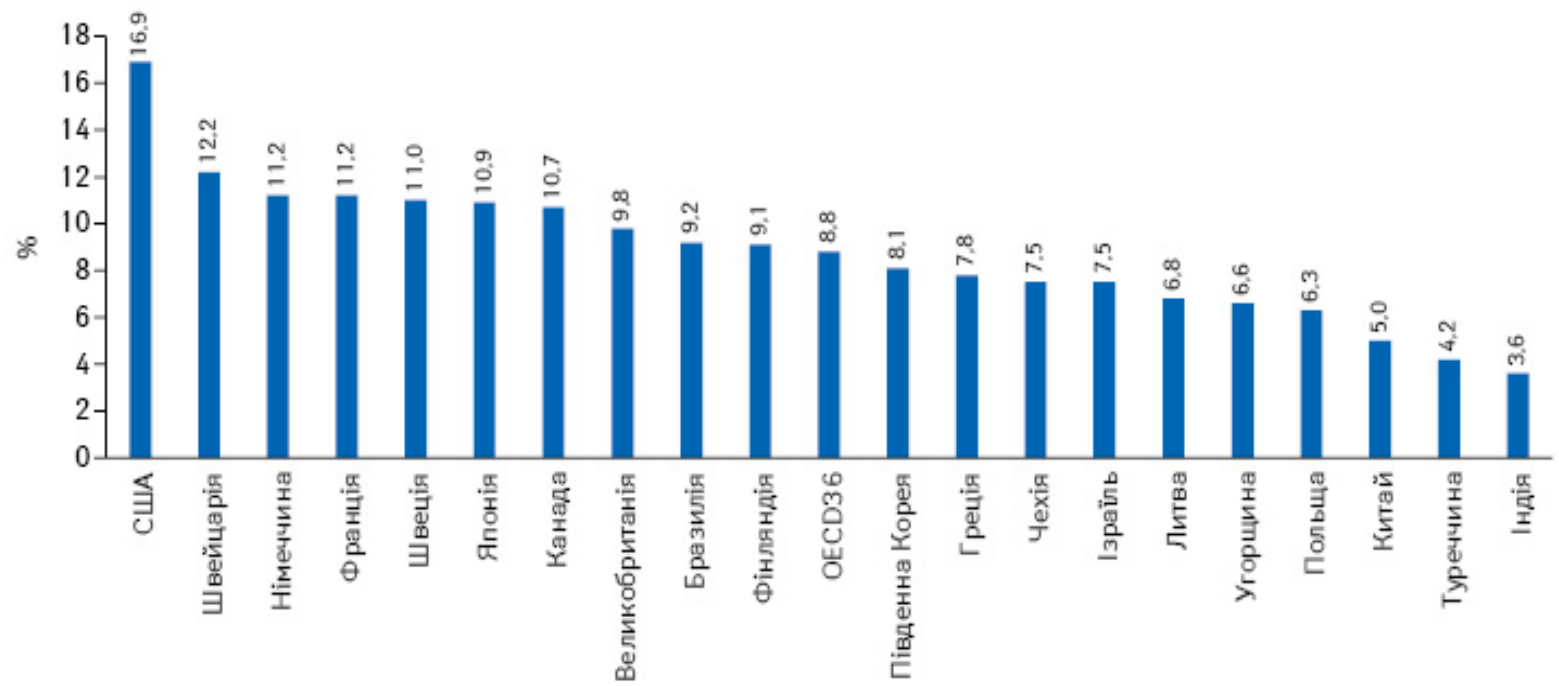

Рис. 1. Питома вага витрат на охорону здоров'я як частка ВВП у окремих країнах - світу у 2018 р.

Джерело: складено за даними Organization for Economic Cooperation and Development, [5]. 
Таблиця Динаміка видатків Зведеного бюджету України на сферу охорони здоров'я у 2015-2019 роках (млн грн)

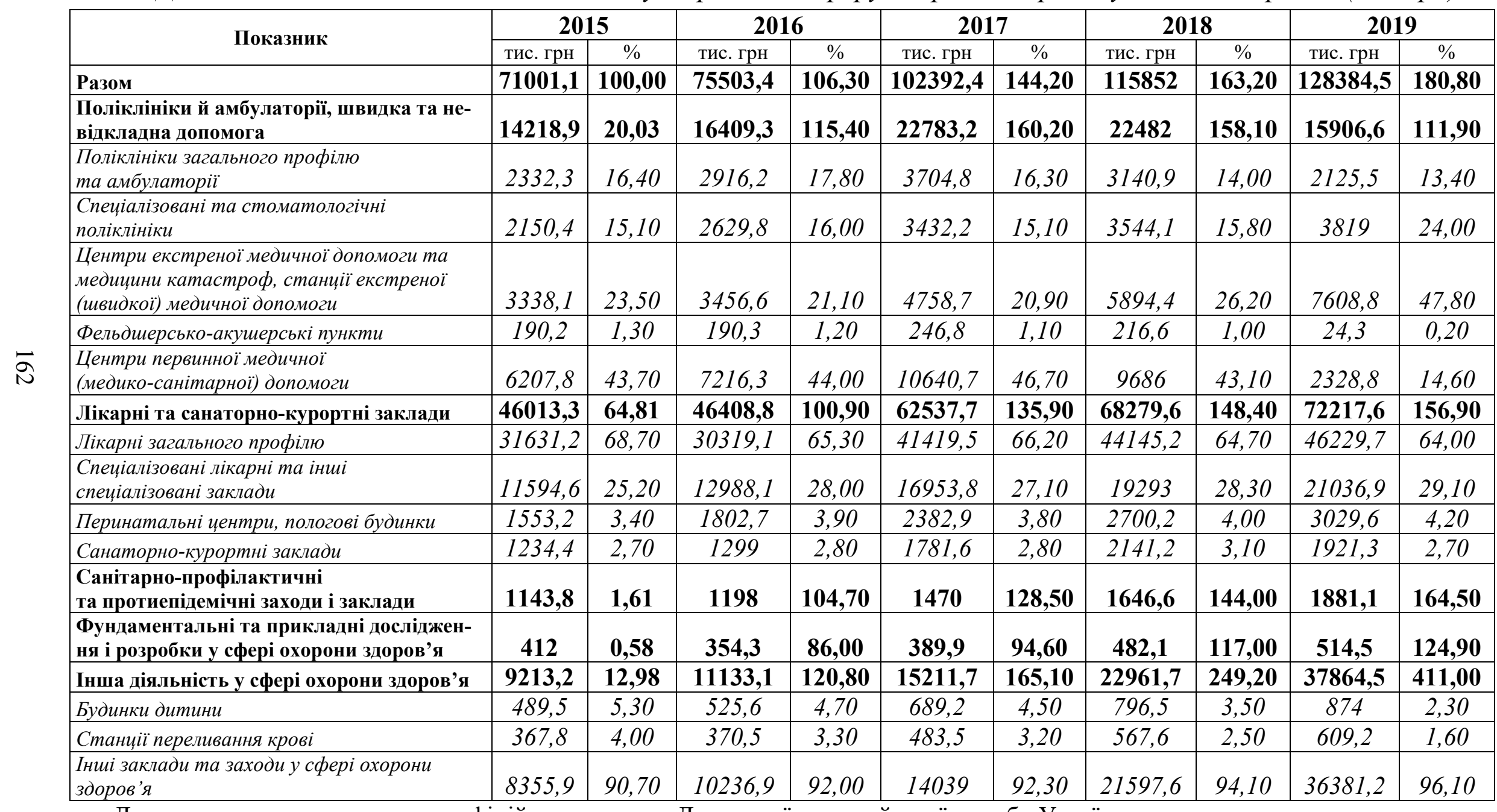

Джерело: складено авторами за офіційними даними Державної казначейської служби України. 
ФІНАНСОВІ РЕСУРСИ: ПРОБЛЕМИ ФОРМУВАННЯ ТА ВИКОРИСТАННЯ

Крім того, якщо враховувати, що рівень ВВП на душу населення в Україні є значно нижчим у порівнянні з більшістю провідних країн світу, можна констатувати, що питання належного фінансового забезпечення сфери охорони здоров'я повинно посідати ключові позиції в майбутніх стратегіях розвитку не лише цієї сфери, але й держави загалом [3; 4].

Наявність значних трансформацій у системі фінансового забезпечення сфери охорони здоров'я протягом останніх років, на жаль, не принесли очікуваного результату, саме тому необхідність поглиблення та деталізації теоретико-методологічного арсеналу іiі функціонування за таких умов набувають особливого значення та актуальності. Вважаємо, що питання належного фінансового забезпечення сфери охорони здоров'я нині переважно залишається у площині перерозподілу державних фінансових ресурсів. Це твердження зумовлено багатьма факторами, пов'язаними з можливостями його формування, а саме:

- по перше, оптимізацію обсягів фінансового забезпечення сфери охорони здоров'я можна здійснити за рахунок запровадження обов'язкового медичного страхування, що дозволить здійснювати акумуляцію додаткових фондів фінансових ресурсів у страхових компаніях, забезпечуючи повне покриття страхових випадків. Проте запровадження обов'язкового медичного страхування обмежується відсутністю та складністю практичного застосування чіткого фінансового механізму його здійснення в сучасних умовах. Основною перешкодою $є$ доступність практичного впровадження обов'язкової страхової медицини, оскільки переважна частина населення, ймовірно, буде не в змозі сплачувати обов'язкові страхові платежі, зокрема соціально незахищені верстви населення, які потребують посиленої уваги з боку сфери охорони здоров'я;

- по друге, наявна думка щодо можливості часткової компенсації страхових платежів з обов'язкового медичного страхування працездатних осіб за рахунок працедавців, на наш погляд, також $є$ не достатньо обгрунтованою, оскільки це посилить фінансове навантаження на підприємства, сформує додаткові передумови для зростання тіньового сектору економіки. Цільове спрямування частини податкових надходжень від окремих видів податків на сферу охорони здоров'я, на наше переконання, буде мати позитивний, проте не визначальний вплив на рівень ії фінансового забезпечення. У Національній стратегії реформування системи охорони здоров'я на 2015-2020 роки, окреслено можливість впровадження цільових податків на алкоголь/тютюн та шкідливі для здоров'я продукти, які повинні пропонуватися як додаткове джерело грошових ресурсів, асигнованих, передусім, на реімбурсацію ліків та розвиток первинної медичної допомоги [6].

Беззаперечно, встановлення фіксованого обсягу обов'язкових страхових платежів із медичного страхування дозволить закріпити їх цільове призначення за сферою охорони здоров'я, проте фактичний обсяг бюджетного фінансового забезпечення не зазнає суттєвих змін. Проте до моменту належного рівня розвитку медичного страхового ринку, питання фінансового забезпечення сфери охорони здоров'я в нашій країні залишається у площині перерозподілу державних фінансових ресурсів, підвищення конкурентоспроможності та результативності функціонування національної економіки, активізації страхового ринку.

Відповідно до Національної стратегії реформування системи охорони здоров'я на 2015-2020 роки [6] зазначено, що «збільшення державних витрат без зміни інфраструктури не забезпечить вирішення наявних проблем». Тобто держава 3 метою підвищення якості послуг сфери охорони здоров'я спрямовує зусилля на зменшення мережі закладів, 3 одночасним збільшенням обсягів їх індивідуального фінансування. Однак запропонований підхід посилює питання доступності медичного обслуговування, особливо у віддалених населених пунктах, які не мають територіального закладу охорони здоров'я $[1 ; 2]$.

Висновки та пропозиції. Охорона здоров'я, безумовно, виступає ключовою сферою національної економіки, результативне функціонування якої передусім визначається іiі спроможністю забезпечити належний рівень медичного обслуговування всього населення, здатністю сформувати тенденції зростання тривалості життя, підвищити рівень продуктивності праці. Саме тому пошук та практичне застосування відповідних 
фінансових інструментів і механізмів, спроможних сформувати необхідний рівень фінансового забезпечення достатнього для запровадження якісно нових інноваційних змін технічного забезпечення та організації фінансових відносин є ключовим стратегічним пріоритетом розвитку сфери охорони здоров'я.

У розвиток поширеної думки про те, що пошук стратегічних перспектив розвитку сфери охорони здоров'я $є$ малоефективним в умовах динамічних трансформацій фінансових i соціальних відносин, хочемо зазначити, що фундаментальність цієї сфери зумовлює необхідність їх подальшого пошуку, що особливо актуалізується в умовах обмеженості фінансової спроможності держави та низького рівня доходів переважної частини населення.

Вирішення глобального питання, пов'язаного із забезпеченням якісного нового підходу до функціонування та розвитку сфери охорони здоров'я, дасть змогу забезпечити збереження людського капіталу, сприятиме накопиченню трудового потенціалу, зменшить соціальне навантаження на бюджети відповідних рівнів, сформує фундамент для посилення конкурентоспроможності національної економіки та зростання рівня життя суспільства.

\section{Список використаних джерел}

1. Борщ В. І. Дослідження функціональної системи управління фінансовими механізмами в сфері охорони здоров'я України. Ринкова економіка: сучасна теорія і практика управління. 2020. T. 19, № 2(45). С. 144-168.

2. Горин В. П. Формування фінансових ресурсів охорони здоров'я в контексті виконання критеріїв економічної безпеки. Наукові записки. Серія «Економіка». 2013. Вип. 23. С. 216-221.

3. Забаштанський М. М., Ридзель Ю. М., Драгунов Д. М., Журман С. М. Світовий досвід державного регулювання сфери охорони здоров’я. Науковий вісник Полісся. 2019. № 2(18). С. 15-21.

4. Кичко I. I. Макроекономічний механізм фінансування охорони здоров'я. Фінанси України. 2003. № 4. С. 71-76.

5. Лук'янчук $Є$. Рахуємо чужі гроші: де послуги у сфері охорони здоров'я найдешевші, а де - найдорожчі? 2019 p. URL: https://www.apteka.ua/article/524775.

6. Національна стратегія реформування системи охорони здоров'я на 2015-2020 роки. URL: https://moz.gov.ua/uploads/0/691-strategiya.pdf.

7. Онишко С. В., Шевчук Ю. В. Проблеми фінансового забезпечення охорони здоров'я в Україні в контексті оптимізації співвідношення між справедливістю та ефективністю. Ефективна економіка. 2018. № 12. URL: www.economy.nayka.com.ua.

8. Сафонов Ю. М., Борщ В. І. Стратегічний менеджмент закладів охорони здоров'я: загальні принципи та особливості застосування в галузі охорони здоров'я України. Актуальні проблеми економіки. 2019. № 8(218). С. 62-69.

9. Про схвалення Стратегії реформування системи управління державними фінансами на 2017-2020 роки : Розпорядження Кабінету Міністрів України від 8 лютого 2017 р. № 142-р. URL :https://www.kmu.gov.ua/npas/249797370.

10. Тулай О. І. Фінансове забезпечення охорони репродуктивного здоров'я в умовах трансформаційної економічної системи : дис. ... канд. екон. наук: 08.04.01 / ТНЕУ. Тернопіль, 2005. 208 с.

11. Шкарлет С. М., Гонта О. І., Дубина М. В. Системний підхід до вивчення економічних явищ. Науковий вісник Полісся. 2016. № 4. С. 9-17.

\section{References}

1. Borshch, V. I. (2020). Doslidzhennia funktsionalnoi systemy upravlinnia finansovymy mekhanizmamy $\mathrm{v}$ sferi okhorony zdorovia Ukrainy [Research of the functional management system of financial mechanisms in the field of health care of Ukraine]. Rynkova ekonomika: suchasna teoriia i praktyka upravlinnia - Market economy: modern theory and practice of management, 19(2(45)), pp. 144-168.

2. Horyn, V. P. (2013). Formuvannia finansovykh resursiv okhorony zdorovia v konteksti vykonannia kryteriiv ekonomichnoi bezpeky [Formation of financial resources of health care in the context of fulfillment of criteria of economic safety]. Naukovi zapysky. Seriia "Ekonomika" Proceedings. Economics series, 23, pp. 216-221.

3. Zabashtanskyi, M. M., Rydzel, Yu. M., Drahunov, D. M., Zhurman, S. M. (2019). Svitovyi dosvid derzhavnoho rehuliuvannia sfery okhorony zdorovia /World experience of state regulation of health care]. Naukovyi visnyk Polissia - Scientific Bulletin of Polissia, (2(18)), pp. 15-21. 
ФІНАНСОВІ РЕСУРСИ: ПРОБЛЕМИ ФОРМУВАННЯ ТА ВИКОРИСТАННЯ

4. Kychko, I. I. (2003). Makroekonomichnyi mekhanizm finansuvannia okhorony zdorovia. Finansy Ukrainy [Macroeconomic health financing mechanism]. Finansy Ukrainy - Finance of Ukraine, 4, pp. 71-76.

5. Lukianchuk, Ye. (2019). Rakhuiemo chuzhi hroshi: de posluhy u sferi okhorony zdorovia naideshevshi, a de - naidorozhchi? [We count other people's money: where are the cheapest health services and where are the most expensive?]. https://www.apteka.ua/article/524775.

6. Natsionalna stratehiia reformuvannia systemy okhorony zdorovia na 2015-2020 roky [National health care reform strategy for 2015-2020]. [2020]. https://moz.gov.ua/uploads/0/691-strategiya.pdf.

7. Onyshko, S. V., Shevchuk, Yu. V. (2018). Problemy finansovoho zabezpechennia okhorony zdorovia v Ukraini v konteksti optymizatsii spivvidnoshennia mizh spravedlyvistiu ta efektyvnistiu [Problems of financial provision of health care in Ukraine in the context of optimizing the relationship between fairness and efficiency]. Efektyvna ekonomika - Efficient economy, (12). www.economy.nayka.com.ua.

8. Safonov. Yu. M., Borshch. V. I. (2019). Stratehichnyi menedzhment zakladiv okhorony zdorovia: zahalni pryntsypy ta osoblyvosti zastosuvannia $\mathrm{v}$ haluzi okhorony zdorovia Ukrainy. [Strategic management of health care institutions: general principles and features of application in the field of health care of Ukraine]. Aktualni problemy ekonomiky - Actual problems of economics, (8(218)), pp. 62-69.

9. Pro skhvalennia Stratehii reformuvannia upravlinnia derzhavnymy finansamy na 2017-2020 roky [Public Finance Management Reform Strategy for 2017-2020], Order of the Cabinet of Ministers of Ukraine № 142-p. (08.02.2017) (Ukraine). https://www.kmu.gov.ua/npas/249797370.

10. Tulai, O. I. (2005). Finansove zabezpechennia okhorony reproduktyvnoho zdorovia $v$ umovakh transformatsiinoi ekonomichnoi systemy /Financial support for reproductive health in a transformational economic system]. [PhD dissertation, TNEU1.

11. Shkarlet, S. M., Honta, O. I., Dubyna, M. V. (2016). Systemnyi pidkhid do vyvchennia ekonomichnykh yavyshch [A systematic approach to the study of economic phenomena]. Naukovyi visnyk Polissia - Scientific Bulletin of Polissia, (4), pp. 9-17.

Роговий Андрій Віталійович - доктор економічних наук, професор, професор кафедри туризму, Націона-

льний університет «Чернігівська політехніка» (вул. Шевченко, 95, м. Чернігів, 14035, Україна).

Роговой Андрей Витальевич - доктор экономических наук, профессор, профессор кафедры туризма, Национальный университет «Черниговская политехника» (ул. Шевченко, 95, г. Чернигов, 14035, Украина).

Rogovyi Andrii - Doctor of Economics, Professor, Professor of Department of Tourism, Chernihiv Polytechnic National University (95 Shevchenka Str., 14035 Chernihiv, Ukraine).

E-mail: rogovoy1976@ukr.net

ORCID: https://orcid.org/0000-0001-5445-214X

ResearcherID: F-7319-2016

Дубина Максим Вікторович - доктор економічних наук, професор, завідувач кафедри фінансів, банківської справи та страхування, Національний університет «Чернігівська політехніка» (вул. Шевченка, 95, м. Чернігів, 14035, Україна).

Дубина Максим Викторович - доктор экономических наук, профессор, заведующий кафедрой финансов, банковского дела и страхования, Национальный университет «Черниговская политехника» (ул. Шевченко, 95 , г. Чернигов, 14035, Украина).

Dubyna Maksym - Doctor of Economics, Professor, Head of Department of Finance, Banking and Insurance, Chernihiv Polytechnic National University (95 Shevchenka Str., 14035 Chernihiv, Ukraine).

E-mail: maksim-32@ukr.net

ORCID: http://orcid.org/0000-0002-5305-7815

ResearcherID: F-3291-2014

Забаштанська Тетяна Володимирівна - кандидат економічних наук, доцент, доцент кафедри маркетингу, PR-технологій та логістики, Національний університет «Чернігівська політехніка» (вул. Шевченко, 95, м. Чернігів, 14035, Україна).

Забаштанская Татьяна Владимировна - кандидат экономических наук, доцент, доцент кафедры маркетинга, PR-технологий и логистики, Национальный университет «Черниговская политехника» (ул. Шевченко, 95, г. Чернигов, 14035, Украина).

Zabashtanska Tatiana - Candidate of Economic Sciences, Associate Professor, Associate Professor of Marketing, PRTechnology and Logistics, Chernihiv Polytechnic National University (95 Shevchenka Str., 14035 Chernihiv, Ukraine). E-mail: tamza.cn@gmail.com

ORCID: http://orcid.org/ 0000-0002-5086-3651

ResearcherID: M-4471-2014

Роговий А., Дубина М., Забаштанська Т. Стратегічні пріоритети розвитку сфери охорони здоров'я в Україні: фінансові аспекти. Проблеми і перспективи економіки та управління. 2020. № 3(23). С. 158-165. 